\title{
Analysis of the Application of Management Control System for Fiduciary Installment Credit (KREASI) at PT Pegadaian Medan City Region
}

\section{Analisis Penerapan Sistem Pengendalian Manajemen Penyaluran Kredit Angsuran Fidusia (KREASI) pada PT Pegadaian Wilayah Kota Medan}

\author{
Maryam Batubara 1); Purnama Rahmadhani Silalahi 2); Marwiyah Siregar 2); Ella Sriwahyuningih ${ }^{3)}$ \\ 1,2) Universitas Is/am Negeri Sumatera Utara \\ Email: 2) purnamaramadani3@uinsu.ac.id; ${ }^{2)}$ ellasriwahyuningsih7@gmail.com; ${ }^{2)}$ \\ siregaranjalimarwiyah@gamil.com
}

\section{How to Cite : \\ ARTICLE HISTORY \\ Received [22 Desember 2021] \\ Revised [30 Desember 2021] \\ Accepted [16 Januari 2022] \\ KEYWORDS \\ Implementation of \\ Management Control System, \\ Fiduciary Installment Credit \\ Distribution}

Batubara, M., Silalahi, P R., Siregar, M., Sriwahyuningih, E. (2022). Analysis of the Application of Management Control System for Fiduciary Installment Credit (KREASI) at PT Pegadaian Medan City Region. Jurnal Ekonomi Manajemen Akuntansi Dan Keuangan, 3(1). DOI: https://doi.org/10.53697/emak.v3i1

This is an open access article under the $C C-B Y$-SA license

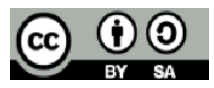

\section{ABSTRAK}

Sistem pengendalian manajemen merupakan sistem yang digunakan untuk mempengaruhi para anggotanya agar menimplementasikan strategi-strategi secara efisien dan efektif dalam rangka mencapai tujuan-tujuan organisasi. Tujuan dalam penelitian ini adalah untuk mengetahui bagaimana penerapan sistem pengendalian manajemen pada PT Pegadaian Wilayah Kota Medan. PT. Pegadaian juga memerlukan adanya suatu pengendalian guna tercapainya tujuan perusahaan secara menyeluruh. Pengendalian ini bersifat preventif dan pengendalian represif. Untuk mencapai tujuan tersebut memerlukan sistem pengendalian manajemen yang baik sehingga kredi ytersebut tidak bermasalah. Tujuan penelitian ini adalah penerapan sistem pengendalian manajemen penyaluran Kredit Angsuran Fidusia (KREASI) pada PT Pegadaian Wilayah Kota Manado. Metode analisis yang digunakan adalah analisis deskriptif. Hasil analisis menunjukkan bahwa Proses pemberian Kredit Angsuran Sistem Fidusia (KREASI), pada PT. Pegadaian Wilayah Manado telah dilakukan dengan baik oleh pegawai-pegawai yang kompeten di bidangnya masing-masing sera memiliki kejujuran dan dedikasi yang tinggi dalam menjalankan tugasnya Pemisahan tugas juga telah dilakukan dengan baik pada setiap proses pemberian Kredit Angsuran Sistem Fidusia (KREASI), pada PT. Pegadaian Wilayah Manado. PT Pegadaian Wilayah Manado telah menerapkan prosedur otorisasi yang tepat pada semua proses pemberian Kredit Angsuran Sistem Fidusia (KREASI), yaitu pada saat proses permohonan kredit gadai petugas yang berwenang adalah penaksir, pada saat proses analisis kredit gadai petugas yang berwenang untuk menganalisis kredit adalah Kuasa Pemutus Kredit (KPK), pada saat proses penarikan kredit petugas yang berwenang adalah kasir, sedang untuk proses monitoring petugas yang berwenang untuk melakukan pengawasan adalah kepala cabang

\section{ABSTRACT}

Management control system is a system used to influence its members to implement strategies efficiently and effectively in order to achieve

234 | Maryam Batubara, Purnama Rahmadhani Silalahi, Marwiyah Siregar, Ella Sriwahyuningih; Analysis of the Application of... 
organizational goals. The purpose of this study was to determine how the implementation of the management control system at PT Pegadaian Medan City Region. PT. Pawnshops also require a control in order to achieve the company's overall goals. This control is preventive and repressive control. To achieve this goal requires a good management control system so that the credit is not problematic. The purpose of this study is the application of a management control system for the distribution of Fiduciary Installment Loans (KREASI) at PT Pegadaian Manado City Region. The analytical method used is descriptive analysis. The results of the analysis show that the process of providing Installment Loans for the Fiduciary System (KREASI), at PT. The Manado Regional Pawnshop has been carried out well by competent employees in their respective fields who have high honesty and dedication in carrying out their duties. Separation of duties has also been carried out well in each process of providing Fiduciary Installment Loans (KREASI), at PT. Manado Regional Pawnshop. PT Pegadaian Manado Region has implemented proper authorization procedures in all processes of providing Fiduciary Installment Loans (KREASI), namely at the time of the mortgage loan application process, the authorized officer is the estimator, during the pawn credit analysis process the authorized officer to analyze credit is the Power of Attorney Credit (KPK), during the credit withdrawal process the authorized officer is the cashier, while for the monitoring process the officer authorized to carry out supervision is the branch head

\section{PENDAHULUAN}

PT. Pegadaian adalah suatu lembaga keuangan non perbankan sesuai dengan Peraturan Pemerintah Republik Indonesia No 103 Tahun 2000 tentang - PT. Pegadaian yang diberi tugas dan wewenang untuk menyelenggarakan kegiatan usaha menyalurkan uang pinjaman atas dasar hukum gadai, dalam hal ini mampu menjadi alternatif karena sistem pelayanannya yang melalui prosedur sederhana cepat dan mudah sesuai dengan mottonya "Mengatasi Masalah Tanpa Masalah. Berbeda dengan lembaga keuangan bank yang pemberian kredit berdasarkan pada jenis usaha dengan jaminan, baik itu benda bergerak dan tidak bergerak, Pegadaian memberikan kreditnya didasarkan pada nilai barang jaminan yang diserahkan tanpa memperhatikan penggun aan kredit tersebut. Tujuannya ikut meningkatkan perekonomian dengan cara memberikan uang pinjaman berdasarkan hukum gadai kepada masyarakat kecil, agar terhindar dari praktek pinjaman uang dengan bunga yang tidak wajar.

Tekanan dari rentenir kepada masyarakat terlebih khusus masyarakat kota Manado yang membutuhkan dana yang cepat, memberikan peluang kepada rentenir untuk menetapkan bunga yang cukup tinggi sekitar (20\%) per bulan sesuai pengamatan dan observasi, sehingga Manajemen PT. Pegadaian melakukan ekspansi besar-besaran dengan membuka unit-unit Pelayanan Cabang yang beroperasi dan tersebar di seluruh wilayah Indonesia baik daerah perkotaan maupun pedesaan, hal ini juga dirasakan oleh PT. Pegadaian Wilayah Kota Manado dan seiring dengan tujuan PT. Pegadaian untuk meningkatkan kesejehteraan rakyat. Peranan PT. Pegadaian di mata masyarakat tetap penting terutama akibat kebutuhan ekonomis finansial, salah satu dari beberapa produk PT. Pegadaian yaitu kredit ran fidusia (kreasi). Kerdit ini diberikan kepada pengusaha mikro dan kecil dengan jaminan BPKB kendaraan bermotor jangka waktu sampai dengan 3 tahun dan angsuran tetap setiap bulan.

Penggunaan kredit tidak selalu seperti yang diharapkan, terbatasnya dana yang tersedia dibanding dengan jumlah permintaan kredit merupakan masalah yang dihadapi PT. Pegadaian. Hal ini tentu saja dapat mengakibatkan kerugian bagi PT. Pegadaian. Oleh karena itu manajer PT. Pegadaian harus mengadakan seleksi terhadap permohonan kredit. Hal-hal tersebut dapat dihindari 
dengan sistem informasi akuntansi yang memadai dalam pemberian kredit. Sistem Informasi Akuntansi dibuat untuk memudahkan manajemen dalam mendapat informasi yang tepat, cepat dan dapat dipercaya bagi pengendalian perusahaan. Dengan adanya informasi yang dibutuhkan, manajemen dapat melakukan pencegahan terhadap tindakan - tindakan penyelewengan wewenang perusahaan. Dengan sistem yang tertata diharapkan dapat menjamin bahwa dalam pelaksanaan pemberian kredit dapat terkendali dan mampu mencegah terjadinya kesalahan yang dapat merugikan PT. Pegadaian dan dapat mencegah terjadinya pemberian kredit yang tidak sehat.

\section{Akuntansi}

\section{LANDASAN TEORI}

Weygant, Kimmel, Kieso (2012) menyatakan bahwa Akuntansi adalah suatu sistem informasi yang mengidentifikasi, mencatat, dan mengkomunikasikan peristiwa-peristiwa ekonomi dari suatu organisasi kepada para pengguna yang berkepentingan. Akuntansi menjelaskan bahwa pada dasarnya akan menghasilkan informasi dari sebuah sistem akuntansi yang ada didalam sebuah entitas atau organisasi bisnis yang disebut dengan informasi akuntansi yang akan dimanfaatkan oleh penguna seperti masyarakat umum, masyarakat intelektual (termasuk didalamnya mahasiswa atau peneliti) dan para pengambil keputusan bisnis dalam organisasi (Pontoh : 2013).

\section{Akuntansi Manajemen}

Handoko (Lakumani dan Morasa, 2015 : 3) menyatakan manajemen adalah proses perencanaan, pengorganisasian, pengarahan dan pengawasan usaha-usaha para anggota organisasi dan penggunaan sumber daya lainnya agar mencapaii tujuan organisasi yang telah ditetapkan. Informasi akuntansi manajemen disajikan kepada manajemen perusahaan dalam berbagai laporan, seperti anggaran, laporan penjualan, laporan biaya produksi, laporan biaya menurut pusat pertanggungjawaban, serta laporan biaya menurut akitivas. Akuntansi manajemen berorientasi pada masa yang akan datang karena menyangkut pengambilan keputusan yang akan dilakukan dimasa yang akan datang. laporan intern ini digunakan manajemen dalam menilai dan mengevaluasi kinerja departemen, manajer, perusahaan dan sebagainya. Akuntasi manajemen menghasilkan informasi untuk pengguna internal seperti manajer, eksekutif, dan pekerja. Akuntansi manajemen mengidentifikasi, mengumpulkan, mengukur, mengklasifikasikan, dan melaporkan informasi yang bermanfaat bagi pengguna internal dalam merencanakan, mengendalikan, dan mengambil keputusan. (Hansen dan Mowen : 2011).

\section{Sistem Pengendalian Manajemen}

Anthony dan Govindarajan (2012) menyatakan bahwa sistem pengendalian manajemen yang baik mempengaruhi perilaku sedemikian rupa sehingga memiliki tujuan yang selaras; artinya tindakan-tindakan individu yang dilakukan untuk meraih tujuan-tujuan pribadi juga akan membantu mencapai tujuan-tujuan organisasi. Sistem pengendalian manajemen adalah sistem yang harus dirancang sedemikian rupa sehingga tindakan-tindakan setiap anggota perusahaan unutk meraih kepentingannya sendiri selaras dengan kepentingan perusahaan.

Sumarsan (2013: 4) menyatakan bahwa sistem adalah suatu kesatuan dan perangkat hubungan-hubungan satu sama lain. Kriteria dari sistem sebagai berikut:

1. Sistem dirancang untuk mencapai tujuan.

2. Elemen dari sistem harus mempunyai rencana yang ditetapkan.

3. Elemen dalam sistem harus berhubungan dan berkaitan dalam mencapai tujuan organisasi pada umumnya dan pencapaian divisi atau departemen pada khususnya.

4. Unsur dasar dari proses (arus informasi, energi, material) lebih penting daripada elemen sistem.

5. Tujuan organisasi lebih penting daripada tujuan divisi atau tujuan departemen.

236 | Maryam Batubara, Purnama Rahmadhani Silalahi, Marwiyah Siregar, Ella Sriwahyuningih; Analysis of the Application of... 
Tujuan Sistem Pengendalian Manajemen

Sumarsan (2013: 7) menyatakan tujuan perancangan suatu sistem pengendalian manajemen.

1. Diperolehnya keandalan dan intergritas.

2. Kepatuhan pada kebijakan, rencana, prosedur, peraturan dan ketentuan yang berlaku. Kepatuhan pada kebijakan, rencana, prosedur, peraturan dan ketentuan yang berlaku dapat dicapai melalui sistem pengendalian manajemen.

3. Melindungi harta perusahaan, pada umumnya pengendalian disusun dan diimplementasikan untuk melindungi harta perusahaan.

4. Pencapain kegiatan yang ekonomis dan efisien, sumber daya bersifat terbatas mendorong organisasi menerapkan prinsip ekonomi.

\section{Struktur Pengendalian Manajemen}

Sistem pengendalian manajemen harus didukung dengan struktur pengendalian yang baik. Struktur pengendalian manajemen adalah elemen-elemen yang membentuk sistem pengendalian itu sendiri yang terdiri atas pusat-pusat pertanggungjawaban. Struktur pengendalian manajemen terdiri atas:

1. Struktur Organisasi. Struktur organisasi yang dipakai akan mempengaruhi pula rancangan sistem pengendalian manajemennya. Pertumbuhan dan perubahan lingkungan organisasi mempengaruhi struktur organsiasi khususnya pada pembentukan departemen-departemen

2. Pendelegasian wewenang dan Tanggung jawab. Setiap pusat pertanggungjawaban mempunyai wewenang sesuai dengan ketentuan yang ditetapkan oleh organisasi yang bersangkutan. Desentralisasi atau pendelegasian wewenang pimpinan kepada bawahannya, pada umumnya dalam suatu organisasi yang relative besar.

3. Pusat Pertanggungjawaban. Pusat pertanggungjawaban adalah bagian atau unit organisasi yang dipimpin oleh manajer yang bertanggung jawab terhadap aktivitas pusat pertanggungjawaban yang dipimpinnya. Suatu organisasi merupakan kumpulan dari berbagai pusat pertanggungjawaban. Menurut Sumarsan (2013) terdapat empat pusat pertanggungjawaban, yaitu :
a. Pusat Biaya (exspense center)
b. Pusat Pendapatan (revenue center)
c. Pusat Laba (profit center)
d. Pusat Investasi (investment center)

\section{Proses Pengendalian Manajemen}

Proses pengendalian manajemen yang baik sebenarnya formal, namun bersifat pengendalian informal masih banyak terjadi. Pengendalian manajemen formal merupakan tahaptahap yang saling berkaitan satu sama lain. Langkah-langkah proses sistem pengendalian manajemen menurut Anthony dan Govindarajan (2012) adalah sebagai berikut :

1. Perumusan dan Perencanaan Strategi. Perumusan merupakan proses penentuan visi, misi, tujuan, sasaran, target (outcome), arah dan kebijakan, serta strategi organisasi. Perumusan strategi merupakan tugas dan tanggung jawab manajemen puncak. Tahap ini merupakan proses penentuan program-program, aktivitas, atau proyek yang akan dilaksanakan oleh suatu organisasi dan penentuan jumlah alokasi sumber daya yang akan dibutuhkan. Perbedaannya dengan perumusan strategi adalah perumusan strategi merupakan proses untuk menentukan strategi sedangkan perencenaan strategi adalah proses untuk menentukan bagaimana mengimplementasikan strategi tersebut. Perencanaan strategi merupakan proses yang sistematik yang memiliki prosedur dan skedul yang jelas. Organisasi yang tidak memiliki atau tidak melakukan perencanaan strategic akan mengalami masalah dalam penganggaran.

2. Penyusunan Anggaran. Anggaran adalah suatu rencana yang dinyatakan secara kuantitatif dinyatakan dalam satuan moneter untuk periode waktu tertentu, biasanya satu tahun. penyusunan anggaran pada dasarnya merupakan proses penetapan peran tiap manajer dalam 
melaksanakan program. Penyusunan Anggaran yang efektif melibatkan setiap unit dalam perusahaan, agar setiap unit tersebut akan merasa bertanggung jawab untuk melaksanakan anggaran yang telah ditetapkan (Tumbuan, 2013: 11).

3. Pelaksanaan dan Pengukuran. Pada tahap ini dilaksanakan pencatatan mengenai berbagai sumber daya yang digunakan dan penerimaan- penerimaan yang dihasilkan. Catatan dan biaya-biaya tersebut digolongkan sesuai dengan program yang telah ditetapkan dan pusatpusat pertanggungjawaban. Penggolongan yang sesuai program dipakai sebagai dasar untuk pemrograman di masa yang akan datang, sedangkan penggolongan yang sesuai dengan pusat tanggung jawab digunakan untuk mengukur kinerja para manajer

4. Evaluasi Kerja. Tahap ini paling penting karena menutup suatu siklus dari proses pengendalian manajemen agar data untuk proses pertanggungjawaban akuntansi dapat dikumpulkan. Evaluasi dilakukan dengan membandingkan antara realisasi anggaran dengan anggaran yang telah ditetapkan sebelumnya. Evaluasi atas kinerja yang dilakukan oleh perusahaan biasa beranekaragam tergantung pada budaya yang dikembangkan dalam perusahaan tersebut.

\section{METODE PENELITIAN}

\section{Jenis Penelitian}

Jenis penelian ini adalah penelitian deskriptif untuk memberikan gambaran cara sistematis dan akurat mengenai fakta, sifat dari hubungan antar fenomena yang diteliti pada suatu perusahaan. Gambaran yang sistematis dan akurat diperoleh dengan mengumpulkan, mengklasifikasikan data sehingga akan memberikan hasil yang konkrit pada permasalahan dan kemudian dilaksanakan analisis sehingga dapat ditarik kesimpulan.

\section{Jenis Data}

Data kualitatif yang dibutuhkan adalah mengenai deskripsi objek penelitian dan catatan perusahaan seperti Buku Standar Operasional Perusahaan

\section{Sumber Data}

Sumber data yang digunakan dalam penelitian ini adalah data sekunder. Data sekunder yang dibutuhkan merupakan data yang diperoleh langsung dari karyawan untuk mendapatkan sejarah singkat PT Pegadaian dan dari staff administrasi kredit untuk mendapatkan penjelasan mengenai pelaksanaan Standar Operasional Perusahaan pemberian kredit mulai dari tahap pengajuan sampai pada tahap pencairan.

Teknik yang digunakan oleh penulis dalam pengumpulan data untuk penelitian ini adalah dengan cara sebagai berikut :

1. Metode Observasi. Metode Observasi yaitu pengamatan langsung pada perusahaan terkait dalam hal ini adalah PT Pegadaian di wilayah Medan sebagai objek penelitian.

2. Metode Wawancara. Wawancara adalah mengajukan pertanyaan kepada karyawan dan pimpinan mengenai hal - hal yang berhubungan dengan pelaksanaan Standar Operasional Perusahaan penyaluran kredit.

3. Metode Dokumentasi. Metode ini adalah mencari data mengenai teori - teori atau hal - hal berupa catatan, transkrip buku, notulen.

\section{Teknik Analisis Data}

Data yang diperoleh kemudian disusun, diolah, dan selanjutnya dilakukan analisis sehingga dapat menghasilkan suatu kesimpulan dengan amenggunakan alat analisis bagan alur berupa flowchart Sistem Akuntansi (SA) dan Data Flow Diagram (DFD) untuk menganalisis masalah dengan cara mendeskripsikan penerapan Sistem Pengendalian manajemen dengan teknik sebagai berikut :

238 | Maryam Batubara, Purnama Rahmadhani Silalahi, Marwiyah Siregar, Ella Sriwahyuningih;

Analysis of the Application of... 
1. Mendapatkan gambaran umum tentang Standar Operasional Perusahaan mengenai penerapan sistem pengendalian manajemen penyaluran kredit angsuran fidusia (kreasi) pada PT Pegadaian Wilayah Kota Medan

2. Memperoleh data penerapan sistem pengendalian manajemen penyaluran kredit angsuran fidusia (kreasi) pada PT Pegadaian Wilayah Kota Medan

3. Menganalisa, penerapan sistem pengendalian manajemen penyaluran kredit angsuran fidusia (kreasi) pada PT Pegadaian Wilayah Kota Medan

4. Dari hasil penelitian kemudian ditarik kesimpulan dan diberikan saran-saran.

\section{Definisi Operasional}

1. Analisis. Pekerjaan yang disusun untuk menjamin adanya perlakuan yang seragam terhadap transaksi- trransaksi perusahaan yang sering terjadi.

2. Penerapan. Penerapan merupakan suatu hal yang berkenaan dengan cara mempraktekkan suatu teori terhadap hal yang benar-benar nyata.

3. Sistem Pengendalian Manajemen. Proses yang integral pada tindakan dan kegiatan yang dilakukan secara terus menerus oleh pimpinan dan seluruh pegawai untuk memberikan keyakinan memadai atas tercapainya tujuan organisasi melalui kegiatan yang efektif dan efisien, keandalan pelaporan keuangan, pengamanan aset negara, dan ketaatan terhadap peraturan perundang-undangan

4. Kredit. Pemberian uang berdasarkan kesepakatan atau persetujuan pinjam-meminjam antara PT Pegadaian dengan pihak peminjam (kreditor), dengan perjanjian pihak peminjam melunasi hutangnya setelah jangka waktu tertentu dengan bunga yang ditentukan.

5. Penyaluran Kredit. Adapun bentuk penyaluran kredit angsuran fidusia (kreasi) pada PT Pegadaian adalah adalah penyerahan sejumlah uang kepada kreditor untuk membiayai usahanya baik kecil, menengah, sampai besar. Penyerahan kredit angsuran fidusia (kreasi) yang diberikan kepada nasabah yang mengajukan permohonan permintaan kredit. Dengan besar pinjaman mulai dari Rp. 5jt - Rp. 100jt dengan syarat dan ketentuan yang berlaku.

\section{Deskripsi Lokasi Penelitian}

\section{HASIL DAN PEMBAHASAN}

Pegadaian Negeri didirikan pertama kali oleh pemerintah Hindia Belanda pada tanggal 1 April 1901 di Kota Sukabumi dengan status Jawatan. Pada tahun 1960, statusnya diubah menjadi Perusahaan Negara (PN), namun diubah kembali Perusahaan Jawatan (Perjan) tahun 1969. Dengan PP No. 10 Tahun 1990 tanggal 10 April 1990 status Perjan Pegadaian diubah menjadi Perusahaan Umum (Perum) Pegadaian guna meningkatkan efisiensi dan produktifitas usaha. Kemudian pada tahun 2012 status Perum Pegadaian berubah menjadi PT. Pegadaian (persero) sesuai dengan PP No. 51 tahun 2011. Salah satu produk PT. Pegadaian adalah memberikan kredit berdasarkan hukum gadai

\section{Hasil Penelitian}

Dari hasil penelitian yang telah dilakukan dapat dilihat bahwa kredit usaha ini hanya bisa diberikan kepada pengusaha mikro dengan ketentuan yang telah ditetapkan. Dalam prosedur pemberian kredit pihak PT. Pegadaian menerapkan konsep 5C yaitu character, capacity, capital, collateral dan condition serta 5P (porty, purpose, payment, profitability, dan protection).

Secara umum yang dijelaskan pada calon debitur, prosedur pemberian Kredit Angsuran Sistem Fidusia (KREASI) terdiri dari 6 tahap yaitu :

1. Tahap permohonan Kredit Angsuran Sistem Fidusia (KREASI)

2. Tahap penyelidikan atas permohonan kredit

3. Tahap Analisis Kredit

4. Tahap keputusan pemberian kredit

5. Tahap pencarian kredit 


\section{Tahap pelunasan kredit}

Secara terperinci tahap - tahap yang dilakukan oleh PT. Pegadaian pada Standar Operasional Prosedur Pemberian Kredit Angsuran Sistem Fidusia (KREASI) adalah sebagai berikut :

\section{Analisa Kredit}

Nasabah yang ingin mengajukan Kredit Angsuran Sistem Fidusia (KREASI) datang ke PT. Pegadaian untuk mendapatkan informasi pemberian kredit. PT. Pegadaian memberikan syaratsyarat yang harus dipenuhi oleh nasabah untuk mendapatkan Kredit Angsuran Sistem Fidusia (KREASI) yaitu :

1. Syarat-syarat untuk kredit komersial

a. Fotocopy KTP Suami -Istri

b. Fotocopy kartu keluarga dan akte nikah Pas foto suami-istri

c. Surat keterangan usaha dari kelurahan Gambar dan dena lokasi usaha Jaminan berupa BPKB mobil

2. Persetujuan

a. Kewenangan memutuskan kredit

b. Jika permohonan diterima maka akan dibuat Surat Pemberitahuan Persetujuan Kredit

b. (SPPK). Jika tidak disetujui berkas akan dikembalikan ke pemohon.

c. Pengembalian surat persetujuan untuk ditandatangani dan dimaterai

d. Membuat Perjanjian Kredit (PK) sesuai dengan format atau ketentuan yang berlaku.

e. Realisasi Kredit (jika seluruh syarat telah terpenuhi)

3. Administrasi Kredit

a. Permohonan Kredit yang telah diputus selanjutnya dituang dalam SPHP

b. Penerima menandatangani perjanjian kredit dan akte pengikatan perjanjian

c. Perjanjian kredit dilakukan secara bawah tangan.

d. Pemantauan

4. Petugas kredit wajib melakukan pemantauan terhadap :

a. Kelancaran pembayaran angsuran

b. Penyelesaian dokumen

Dalam pelaksanaan prosedur kredit PT. Pegadaian Wilayah Kota Medan menggunakan formulir-formulir yang terkait dengan prosedur pemberian kredit, buku catatn dan alat-alat yang dipergunakan dalam transaksi. Prosedur pemberian kredit usaha dimulai dari tahap permohonan kredit oleh calon debitur, penyidikan penelitian berkas kredit, survey lokasi usaha, analisa kredit dan tahap terakhir yaitu pencairan kredit.

\section{Pembahasan}

Untuk Mengetahui apakah penerapan sistem pengendalian manajemen pemberian Kredit Angsuran Sistem Fidusia (KREASI) pada PT. Pegadaian Wilayah Medan telah mamadai dan berjalan sesuai dengan fungsinya Maka penulis mencoba menganalisis penerapan sistem pengendalian manajemen pemberian Kredit Angsuran Sistem Fidusia (KREASI) pada PT. Pegadaian Wilayah Medan.

\section{Personel yang Kompeten dan Dapat Dipercaya}

Dalam proses ini PT. Pegadaian Wilayah Medan memiliki personel yang dapat diandalkan. Yang terlihat dengan adanya personel yang tahu dan paham akan hal-hal dan syarat-syarat yang harus dipenuhi nasabah dalam mengajukan permohonan Kredit Angsuran Sistem Fidusia (KREASI) dan dapat memberikan informasi yang dibutuhkan oleh nasabah yang berkaitan dengan Kredit Angsuran Sistem Fidusia (KREASI).

Keputusan pemberian kredit dilakukan oleh Kuasa Pemutus Kredit (KPK), yang terdiri atas penaksir dan kepala cabang yang masing-masing berperan sebagai penaksir I dan penaksir II.

240 | Maryam Batubara, Purnama Rahmadhani Silalahi, Marwiyah Siregar, Ella Sriwahyuningih;

Analysis of the Application of... 
Keputusan pemberian Kredit Angsuran Sistem Fidusia (KREASI) dilakukan setelah melakukan taksiran atas barang jaminan Pada proses ini Perum Pegadaian memiliki personel yang kompeten dan dapat dipercaya, yang dapat dilihat dengan adanya personel yang memiliki pengetahuan dan kemampuan untuk menganalisis dan memutuskan kredit serta tahu akan tugas dan wewenangnya masing-masing.

Proses realisasi/pencairan kredit dilakukan oleh kasir. Kasir mempunyai tanggung jawab penuh atas dana yang dikeluarkan dan diterima atas nama PT. Pegadaian. Apabila terjadi selisih kas maka kasir akan mempertanggung jawabkan langsung kepada kepala cabang. Pada proses ini terdapat pemisahan tugas antara petugas yang mengeluarkan uang tunai yaitu kasir dengan petugas yang mencatat kredit yaitu bagian administrasi. Hal ini akan memperkecil kemungkinan penyalahgunaan uang pinjaman oleh kasir.

\section{Pemisahan Tugas yang Memadai}

Proses analisis pemberian Kredit Angsuran Sistem Fidusia (KREASI) dilakukan oleh penaksir I, kemudian hasil taksiran dari penaksir I akan ditaksir ulang oleh penaksir II dalam hal ini adalah kepala cabang sebagai bentuk pengawasan dalam pemberian Kredit Angsuran Sistem Fidusia (KREASI). Setelah diadakan penaksiran maka proses analisis dan keputusan pemberian kredit dilakukan oleh KPK.

Pengendalian manajemen pada proses penarikan Kredit Angsuran Sistem Fidusia (KREASI) ditinjau dari pemisahan tugas telah berjalan dengan baik. Pada proses penarikan Kredit Angsuran Sistem Fidusia (KREASI)terdapat pemisahan tugas antara petugas yang melakukan persetujuan penarikan kredit dengan petugas yang melaksanakan penarikan Kredit Angsuran Sistem Fidusia (KREASI) tersebut. Dimana petugas yang melakukan persetujuan atas penarikan kredit gadai adalah KPK, sedangkan petugas pelaksana penarikan kredit gadai adalah kasir.

Pada proses ini pengendalian manajemen yang dilakukan oleh PT Pegadaian Wilayah Medan ditinjau dari pemisahan tugas yang memadai telah dilakukan dengan baik. Pada proses monitoring pemberian Kredit Angsuran Sistem Fidusia (KREASI) telah dilakukan pemisahan tugas antara petugas pelaksana pemberian kredit gadai dengan petugas pengawas pelaksanaan pemberian Kredit Angsuran Sistem Fidusia (KREASI). Petugas pengawas dalam hal ini adalah kepala cabang sebagai pemegang jabatan tertinggi di PT. Pegadaian Wilayah Medan.

\section{Prosedur Otorisasi yang Tepat}

Pada proses ini analisis terhadap permohonan Kredit Angsuran Sistem Fidusia (KREASI) langsung ditangani oleh penaksir, sehingga penaksir dapat langsung mengetahui apakah barang jaminan dari nasabah tersebut layak untuk dijadikan barang jaminan atau tidak. Hal ini dapat mengoptimalkan waktu dan prosedur pemberian Kredit Angsuran Sistem Fidusia (KREASI), baik untuk keperluan nasabah maupun untuk kepentingan PT. Pegadaian itu sendiri.

\section{Dokumen dan Catatan yang Memadai}

Perancangan dan penggunaan dokumen dan catatan pemberian Kredit Angsuran Sistem Fidusia (KREASI) yang dilakukan pada PT. Pegadaian Wilayah Medan sudah memadai. Yang ditunjukkan dengan adanya pengendalian intern berupa formulir dengan nomor urut tercetak untuk semua formulir yang digunakan dalam siklus pemberian kredit; adanya pencatatan terhadap formulir yang telah digunakan, yang belum digunakan dan yang batal digunakan oleh PT Pegadaian Wilayah Medan Malang ke dalam buku pemberian yang diselenggarakan oleh bagian adminstrasi yang dimaksudkan untuk menjaga aset perusahaan.

\section{Kontrol Fisik Aktiva dan Catatan}

Pada proses pemohonan Kredit Angsuran Sistem Fidusia (KREASI), kontrol terhadap fisik aktiva dan catatan dilakukan dengan memeriksa syarat-syarat kelengkapan permohonan kredit yaitu Formulir Permohonan Kredit (FPK) yang diisi oleh nasabah dengan lengkap dan benar, 
fotocopy identitas diri nasabah dan barang jaminan sebagai penjamin atas kredit yang akan diberikan.

Berdasarkan uraian di atas maka PT Pegadaian Wilayah Kota Medan sudah menerpkan sistem pengendalian manajemen penyaluran Kredit Angsuran Fidusia (KREASI) dengan baik karena telah dilaksanakan melalui empat tahapan yaitu tahap Persiapan Kredit, Tahap Analisis Kredit, Tahap Keputusan Kredit dan Tahap Pelaksanaan kredit.

\section{KESIMPULAN DAN SARAN}

1. Personel yang Kompeten dan Dapat Dipercaya. Dalam proses ini PT. Pegadaian Wilayah Medan memiliki personel yang dapat diandalkan. Yang terlihat dengan adanya personel yang tahu dan paham akan hal-hal dan syarat-syarat yang harus dipenuhi nasabah dalam mengajukan permohonan Kredit Angsuran Sistem Fidusia (KREASI) dan dapat memberikan informasi yang dibutuhkan oleh nasabah yang berkaitan dengan Kredit Angsuran Sistem Fidusia (KREASI).

2. Pemisahan Tugas yang Memadai. Proses analisis pemberian Kredit Angsuran Sistem Fidusia (KREASI) dilakukan oleh penaksir I, kemudian hasil taksiran dari penaksir I akan ditaksir ulang oleh penaksir II dalam hal ini adalah kepala cabang sebagai bentuk pengawasan dalam pemberian Kredit Angsuran Sistem Fidusia (KREASI). Setelah diadakan penaksiran maka proses analisis dan keputusan pemberian kredit dilakukan oleh KPK.

3. Prosedur Otorisasi yang Tepat. Pada proses ini analisis terhadap permohonan Kredit Angsuran Sistem Fidusia (KREASI) langsung ditangani oleh penaksir, sehingga penaksir dapat langsung mengetahui apakah barang jaminan dari nasabah tersebut layak untuk dijadikan barang jaminan atau tidak. Hal ini dapat mengoptimalkan waktu dan prosedur pemberian Kredit Angsuran Sistem Fidusia (KREASI), baik untuk keperluan nasabah maupun untuk kepentingan PT. Pegadaian itu sendiri.

\section{DAFTAR PUSTAKA}

Abdurrohman, M. (2015). PENGARUH PENGENDALIAN INTERN DAN PENILAIAN KREDIT TERHADAP NON PERFORMING LOAN (NPL) PADA KOPERASI SIMPAN PINJAM DI KABUPATEK KUDUS. Journal Of Accounting, 1(1).

Alfian, D., Iriyadi, I., \& Pramiudi, U. (2013). Anggaran Biaya Sebagai Alat Pengendalian Manajemen Pada PT Asuransi Jiwasraya (Persero) Bogor. Jurnal IImiah Akuntansi Kesatuan, 1(3), 193-202.

MUCHAMAD ROBI CAHYONI, M. R. C. (2019). PENGARUH STRUKTUR PENGENDALIAN INTERN TERHADAP KELANCARAN PENGEMBALIAN KREDIT PADA KSP BANGUN JAYA MAKMUR DI JOMBANG (Doctoral dissertation, UNIVERSITAS ISLAM MAJAPAHIT MOJOKERTO).

Pakekong, G. (2016). Analisis Penerapan Sistem Pengendalian Manajemen Penyaluran Kredit Angsuran Fidusia (Kreasi) Pada Pt Pegadaian Wilayah Kota Manado. Jurnal Berkala Ilmiah Efisiensi, 16(4).

Saraswati, L., \& Yadnyana, I. K. (2014). Pengaruh Struktur Pengendalian Intern Terhadap Kelancaran Pengembalian Kredit Pada Koperasi Simpan Pinjam Di Kota Denpasar. Jurnal Akuntansi Universitas Udayana, 7(1), 122-134.

242 | Maryam Batubara, Purnama Rahmadhani Silalahi, Marwiyah Siregar, Ella Sriwahyuningih; Analysis of the Application of... 